Jurnal Pemberdayaan: Publikasi Hasil Pengabdian kepada Masyarakat

Vol. 2, No. 2, Agustus 2018, Hal. 315-320

ISSN: 2088 4559; e-ISSN: XXXX-XXXX

DOI:

\title{
PEMBERDAYAAN MASYARAKAT MELALUI PENGUATAN POLA ASUH ORANGTUA TERHADAP TUMBUH KEMBANG ANAK DALAM PANDANGAN ISLAM
}

\author{
Irvan Budh Handaka ${ }^{1}$, Bagus Julian Hikmy ${ }^{2}$, Aida Musawwamah ${ }^{3}$ \\ Universitas Ahmad Dahlan, Yogyakarta \\ Email: irvan.handaka@bk.uad.ac.id
}

\begin{abstract}
ABSTRAK
Kegiatan ini bertujuan memberdayakan masyarakat Nomporejo melalui penguatan pola asuh orang tua terhadap tumbuh kembang anak dalam pandangan Islam. Salah satu permasalahan yang ada di masyarakat Desa Nomporejo, Kecamatan Galur, Kabupaten Kulon Progo, D.I.Y adalah persoalan stunting. Mahasiswa KKN UAD bekerjasama dengan BKKBN DIY menyelenggarakan program pencegahan stunting. Permasalahan stunting merupakan asupan pangan/gizi yang tidak sesuai dengan kebutuhan gizi sehingga antara asupan pangan/gizi dengan kesehatan harus seimbang. Permasalahan ini bukan hanya berdasarkan kekurangan kebutuhan gizi, disamping itu juga terdapat faktor risiko pola asuh orangtua sang anak. Pola asuh orang tua sangat berpengaruh pada perkembangan kepribadian dan sosialisasi semua usia, termasuk remaja. Metode pelaksanaan program KKN meliputi: pendidikan masyarakat, difusi IPTEK, dan praktek langsung. Hasil dan dampak dari kegiatan KKN ini adalah: 1) tercipta kesadaran masyarakat sasaran tentang pola asuh yang ideal, 2) peningkatan pengetahuan masyarakat dalam memperhatikan tumbuh kembang anak.
\end{abstract}

Kata kunci : Penguatan Pola Asuh, Tumbuh Kembang Anak, Pandangan Islam

\begin{abstract}
The aim of the program is to empower the Nomporejo community through strengthening the parenting style of the child's growth in the view of Islam. One of the problems in the community of Nomporejo Village, Galur District, Kulon Progo Regency, D.I. Yogyakarta is an inventory of village loci points of stunting problems. UAD KKN in collaboration with DIY BKKBN created a stunting prevention program. The problem of stunting is food / nutrition intake that is not in accordance with nutritional needs so that the intake of food / nutrition with health must be balanced. This problem is not only based on lack of nutritional needs, besides that there are also risk factors for parenting the child's parents. Parenting is very influential on personality development and socialization of all ages, including adolescents. The methods for implementing the KKN program include: community education, diffusion of science and technology, and direct practice. The impacts of the KKN activities are: 1) creating awareness of the target community about ideal parenting, 2) increasing community knowledge in paying attention to children's growth and development.
\end{abstract}

Keywords: Strengthening Foster Patterns, Child Growth, Islamic View 


\section{PENDAHULUAN}

Keluarga memberikan dasar pembentukan kepribadian, tingkah laku, watak, moral dan pendidikan anak. Keluarga yang ideal adalah keluarga yang dapat menjalankan peran dan fungsi dari keluarga dengan baik sehingga akan terwujud hidup yang sejahtera. Untuk dapat mewujudkan keluarga yang sejahtera, faktor dalam keluarga yang mempunyai peranan penting adalah penerapan pola asuh orang tua (Sipahutar, 2009). Permasalahan keluarga yang dialami oleh sebagian masyarakat Nomporejo adalah kurangnya kesadaran tentang tumbuh kembang anak dalam pandangan Islam. Oleh karena itu, perlu dicari solusi-solusi yang tepat untuk mengatasi permasalahan tersebut.

Tujuan pelaksanaan program yaitu memberdayakan masyarakat Nomporejo melalui penguatan polaasuh orang tua terhadap tumbuh kembang anak dalam pandangan Islam. Pola asuh merupakan suatu proses mendidik, membimbing, dan mendisiplinkan serta melindungi anak untuk mencapai kedewasaan sesuai dengan norma dalam masyarakat. Pola asuh dapat bekerja sangat baik ketika diterapkan pada anak secara individu dan dalam situasi yang spesifik sehingga dapat terbina hubungan yang baik antar remaja dan orang tua (Sipahutar, 2009). Hubungan yang baik antara orang tua dan remaja akan membantu pembinaan diri remaja dalam upaya menyelesaikan setiap tugas perkembangannya. Tugas perkembangan yang paling penting pada saat remaja adalah perkembangan sosialisasi. Sosialisasi adalah perolehan kemampuan berperilaku sesuai dengan tuntutan sosial (Hurlock, 2006).

Berdasarkan permasalahan yang telah dikemukakan di atas, mahasiswa KKN UAD menyelanggarakan kegiatan yang mendukung tercapainya tujuan yaitu. memberdayakan masyarakat Nomporejo melalui penguatan pola asuh orang tua terhadap tumbuh kembang anak dalam pandangan Islam. Kegiatan-kegiatan yang telah dilaksanakan berupa kegiatan: pelatihan mengenai token ekonomi serta cara penerapannya, memberi wawasan tentang modifikasi perilaku dengan Reinforcement, Menyelenggarakan pembuatan jajanan sehat berupa Jelly sayur, dan Praktek cuci tangan yang benar dan bersih kepada anak.

\section{METODE}

Kegiatan ini menggunakan metode pendidikan masyarakat, difusi IPTEK, dan praktek. Kegiatan dilaksanakan selama dua hari dan melibatkan 27 mahasiswa. Adapun metode, kegiatan, dan JKEMnya dapat dilihat pada tabel berikut. 


\begin{tabular}{|c|c|c|c|c|}
\hline $\begin{array}{l}\mathrm{N} \\
\mathrm{o} .\end{array}$ & $\begin{array}{l}\mathrm{M} \\
\mathrm{e} \\
\mathrm{t} \\
\mathrm{o} \\
\mathrm{d} \\
\mathrm{e}\end{array}$ & Kegiatan & $\begin{array}{c}\text { JKE } \\
\mathrm{M}\end{array}$ & $\begin{array}{l}\text { Jumlah } \\
\text { mahasisw } \\
\text { a yang } \\
\text { terlibat }\end{array}$ \\
\hline \multirow{2}{*}{1.} & \multirow{2}{*}{$\begin{array}{l}\text { Pe } \\
\text { ny } \\
\text { ul } \\
\text { uh } \\
\text { an }\end{array}$} & $\begin{array}{l}\text { Memberikan materi } \\
\text { mengenai token } \\
\text { ekonomi serta cara } \\
\text { penerapan pada } \\
\text { anak bagi orangtua }\end{array}$ & $\begin{array}{c}1 \times 10 \\
0 "\end{array}$ & 27 \\
\hline & & $\begin{array}{l}\text { Memberi wawasan } \\
\text { tentang modifikasi } \\
\text { perilaku dengan } \\
\text { Reinforcement } \\
\text { pada orangtua. }\end{array}$ & $\begin{array}{c}\text { 1x15 } \\
0 "\end{array}$ & 27 \\
\hline 2. & $\begin{array}{l}\text { Difusi } \\
\text { IPTEK }\end{array}$ & $\begin{array}{l}\text { Menyelenggarakan } \\
\text { pembuatan jajanan } \\
\text { sehat berupa Jelly } \\
\text { sayur }\end{array}$ & $\begin{array}{c}1 \times 20 \\
0 "\end{array}$ & 27 \\
\hline 3. & Praktek & $\begin{array}{l}\text { Praktek cuci tangan } \\
\text { yang benar dan bersih } \\
\text { kepada } \\
\text { Anak }\end{array}$ & $2 \times 50$ & 27 \\
\hline
\end{tabular}

\section{HASIL, PEMBAHASAN, DAN DAMPAK}

Hasilnya dapat dilihat dari aktivitas pelaksanaan program di masyarakat Desa Nomporejo dalam Pemberdayaan Masyarakat Melalui Penguatan Pola Asuh Orangtua Terhadap Tumbuh Kembang Anak dalam Pandangan Islam. Diharapkan dengan kegiatan pola asuh yang dilakukan secara bertahap mampu menerima edukasi mengenai pola asuh secara perlahan dan pasti. Kegiatan bertahap tersebut meliputi modifikasi perilaku, pembuatan jajanan sehat, dan praktek cuci tangan untuk mendorong hidup sehat.

Dampak dari kegiatan KKN ini adalah: 1) tercipta kesadaran masyarakat sasaran tentang pola asuh yang ideal, 2) peningkatan pengetahuan masyarakat dalam memperhatikan tumbuh kembang anak. Santrock (2007) mengklasifikasikan gaya-gaya pola asuh ke dalam gaya yang bersifat otoriter, demokratis, dan permisif. Pengasuhan otoriter adalah gaya yang membatasi dan menguhukum, dimana orang tua mendesak anak untuk mengikuti arahan 
mereka dan menghormati pekerjaan dan upaya mereka. Pengasuhan demokrasi adalah pola asuh yang mendorong anak untuk mandiri namun masih menerapkan batas dan kendali pada tindakan mereka. Pengasuhan permisif adalah gaya dimana orang tua sangat tidak terlibat dalam kehidupan anak.

Ciri khas dari pola asuh demokratis adalah adanya komunikasi yang baik antara anak dan orang tua, dimana orang tua melibatkan diri dan berdiskusi tentang masalah yang dialami anak. Orang tua biasa memberikan pujian apabila anak melakukan hal yang baik dan mengajarkan anak agar melakukan segala sesuatu secara mandiri dengan rasa tanggung jawab dan mencerminkan rasa kasih sayang (Santrock, 2007). Ciri khas dari pola asuh otoriter adalah anak diharuskan mengulang pekerjaan yang dianggap orang tua salah, orang tua mengancam akan memberikan hukuman apabila anak tidak mematuhi perintahnya, dan orang tua menggunakan suara yang keras ketika menyuruh anak untuk melakukan suatu pekerjaan. Pola asuh otoriter menjadikan anak merasa terkekang, kurang bebas, dan terkadang kurang percaya diri, tetapi pola asuh ini akan membentuk anak yang patuh, sopan,dan rajin mengerjakan pekerjaan (Santrock, 2007).

Ciri khas dari pola asuh permisif adalah orang tua tidak memperdulikan apa saja yang dilakukan anak, orang tua jarang sekali mengajak berbicara apalagi berdiskusi tentang masalah anak, serta orang tua selalu memberikan apa saja yang diinginkan anak tanpa banyak bertanya. Pola asuh permisif menjadikan anak berperilaku sesuai dengan keinginannya karena orang tua tidak pernah memberikan aturan ataupun arahan kepada anak sehingga anak tidak tahu apakah perilakunya benar atau salah karena sangat minimnya pengarahan dan aturan dari orang tua (Santrock, 2007).

Orang tua yang memiliki anak hanya satu sampai tiga cenderung mempergunakan pola asuh demokratis karena orang tua memiliki cukup banyak waktu untuk berkomunikasi ataupun berdiskusi dengan anak. Sedangkan orang tua yang memiliki anak enam atau lebih, cenderung memiliki pola asuh otoriter karena dengan pola pengasuhan ini orang tua menganggap dapat tercipta ketertiban dalam rumah dan orang tua dapat mengontrol setiap perilaku anak (Sujata, 2008).

\section{SIMPULAN}

Pelaksanaan kegiatan pemberdayaan masyarakat telah dilaksanakan pada 6-8 Agustus 2018 di 
desa Nomporejo, Kecamatan Galur, Kabupaten Kulon Progo, D.I.Yogyakarta. Kegiatan ini telah berjalan dengan lancar. Kelancaran pelaksanaan program kerja tidak terlepas dari dukungan dan partisipasi dari pihak-pihak terkait sejak awal pelaksanaan hingga selesai KKN Tematik BKKBN di Desa Nomporejo. Pemberdayaan masyarakat yang dilaksanakan berdampak pada penguatan pola asuh orang tua terhadap tumbuh kembangan anak dengan pendekatan secara Islami.

\section{DAFTAR PUSTAKA}

Santrock, J. (2007). Perkembangan Anak Jilid Dua. Jakarta: Erlangga.

Sipahutar, A. (2009). Pola Asuh Orang Tua an Tingkat Kebiasaan Remaja dalam Mengkonsumsi Alkohol di Desa Sirajaoloan Kecamatan Tarutung Kabupaten Tapanuli Utara. Sriksi. Medan: Fakultas Keperawatan USU.

Sujata, A. (2008). Pola Asuh Ibu yang Memiliki Anak Tunggal. Jakarta: Fakultas Psikologi Universitas Gunadarma. 
